Przegląd Prawa Konstytucyjnego

- -ISSN 2082-1212--------

DOI 10.15804/ppk.2017.03.11

$-\mathrm{Nr} 3(37) / 2017$

\title{
Recenzja
}

\section{Jakub Robel, Wptyw Rady Europy na realizację bezpieczeństwa demokratycznego w państwach członkowskich, ISBN: 978-83-8019- 410-6, Wydawnictwo Adam Marszałek, Toruń 2016, ss. 351}

Kluczowym terminem i zarazem merytorycznym rdzeniem książki jest „bezpieczeństwo demokratyczne” (democratic security). Pojęcie „bezpieczeństwa demokratycznego" jest wpisane w aktywność ważnej, regionalnej organizacji stawiającej sobie za cel promocję całego katalogu wartości ujętych w zbiorcze klamry takich pojęć jak rządy prawa, demokracja oraz prawa człowieka. Zagadnienie bezpieczeństwa demokratycznego Rada Europy zaczęła eksponować w okresie wielkiej ustrojowej transformacji państw Europy Środkowej, to jest w latach 90. minionego stulecia.

Pomimo, że wraz z zakończeniem tego procesu - co znalazło wyraz w ustanowieniu ustrojów demokratycznych w tej części Europy - zagadnienie to nie było eksploatowane z wcześniejszą intensywnością, to jednak nie oznacza to, że straciło ono na znaczeniu. Przeciwnie, różnego rodzaju kryzysy konstytucyjne występujące w różnych państwach członkowskich Rady Europy, czynią potrzebę dbałości o respektowanie reguł pluralistycznej demokracji, aktualną. Konkretyzując, dbałość o bezpieczeństwo demokratyczne oznacza między innymi dbałość i szacunek dla konstytucji, sądów konstytucyjnych, wolności i praw jednostki czy wolności mediów. Dynamiczna rzeczywistość ustrojowa ujawniona w ostatnim czasie w niektórych państwach członkowskich Rady 
Europy najpełniej uzmysławia kontynuującą potrzebę i użyteczność Rady Europy w procesie monitorowania kondycji bezpieczeństwa demokratycznego.

Tytuł książki słusznie został zawężony do badań nad koncepcją bezpieczeństwa demokratycznego w państwach członkowskich Rady Europy, gdyż dobrze służy to spójności toczonych w jej ramach rozważań. Natomiast oddziaływanie Rady Europy na obszary zewnętrzne względem jej „granic” to już oddzielna kwestia, to oddziaływanie jest zdecydowanie słabsze. Dodajmy, że obok organów Rady Europy, swoisty monitoring bezpieczeństwa demokratycznego sprawuje także Unia Europejska, ze szczególnym uwzględnieniem roli Parlamentu Europejskiego w tym zakresie. Ważne jest, by aktywność obu organizacji i ich organów w tym obszarze nie przybierała form konkurencji, lecz formy kooperacji.

Praca nie posiada wyłącznie politologicznego charakteru, lecz cechuje ją rozbudowany i pogłębiony aspekt prawny. W pracy przeprowadzono analizę obszernego materiału normatywnego, na który składają się głównie normy traktatowe, normy o charakterze soft law, jak również orzecznictwo. Ponadto, Autor dokonał analizy odpowiednio wyselekcjonowanych dokumentów Rady Europy, ze szczególnym uwzględnieniem dokumentów dotyczących procedury monitoringowej oraz dokumentów ilustrujących mechanizmy wpływu Komisji Weneckiej („Demokracja przez Prawo”) na implementację standardów bezpieczeństwa demokratycznego do praktyki ustrojowej państw. W pracy odnajdujemy także elementy analizy systemowej, pomocnej w prezentacji doniosłości roli odgrywanej przez Radę Europy w działalności na rzez promocji bezpieczeństwa demokratycznego na tle i we współpracy z innymi elementami międzynarodowego systemu ochrony praw człowieka.

Książka obejmuje cztery rozdziały. Jej systematykę oceniam jako zasadniczo spójną. Rządzi nią kryterium logiki. Rozdziały zostały spięte klamrą wstępu oraz zakończenia. Systematyki wewnętrzne rozdziałów korespondują z ty tułami rozdziałów. Konstrukcja książki jest czytelna, wystarczająco uszczegółowiona i w konsekwencji dopracowana, co świadczy o wszechstronnym opanowaniu tematu.

Rozdział pierwszy przynosi ogólną charakterystykę Rady Europy. Uważam, że nigdy dosyć przypominania o celach, zadaniach, organizacji i formach działalności tej organizacji, od dłuższego czasu pozostającej w głębokim cieniu swej wielkiej i zamożnej „siostry”, to jest Unii Europejskiej. Dokonano tu prezentacji genezy i struktury Rady Europy oraz - w oparciu o analizę jej 
wiodących aktów - także prezentacji jej systemu aksjologicznego. Za szczególnie istotny element tej części publikacji należy uznać omówienie wiodących mechanizmów egzekwowania aksjologii Rady Europy w państwach członkowskich, do których zaliczono: procedurę akcesyjną, procedurę monitoringową, orzecznictwo Europejskiego Trybunału Praw Człowieka, działalność Komisarza Praw Człowieka oraz działalność Komisji Weneckiej.

Kolejny, drugi rozdział książki ma charakter koncepcyjny i w szerszym zakresie ujawniła się w nim badawcza samodzielność Autora. Rozpoczynając od słownikowej wykładni pojęcia bezpieczeństwa, łączy on społeczne odczucie bezpieczeństwa z podwalinami procesów państwowotwórczych, wskazując jednocześnie, że niektóre (nie wszystkie) z rodzajów bezpieczeństwa uległy konstytucjonalizacji i wywołują skutki prawne w postaci obowiązków organów władzy publicznej. Interesujący, zaprezentowany w tej części pracy katalog rodzajów bezpieczeństwa obejmuje bezpieczeństwo militarne, bezpieczeństwo polityczne, bezpieczeństwo demokratyczne, bezpieczeństwo socjalne, bezpieczeństwo ekologiczne oraz bezpieczeństwo informacyjne. Zawartość tego katalogu została skorelowana z aksjologią Rady Europy. Następnie, po ogólnej charakterystyce pojęcia bezpieczeństwa demokratycznego - będącego wiodącym przedmiotem publikacji, zgodnie z założeniami analizy systemowej zaprezentowano elementy koncepcji bezpieczeństwa demokratycznego w działalności innych niż Rada Europy organizacji międzynarodowych, a to: Paktu Północnoatlantyckiego, Organizacji Bezpieczeństwa i Współpracy w Europie oraz w Unii Europejskiej.

Rdzeniem publikacji wydaje się być rozdział trzeci, traktujący o aksjologii Rady Europy oraz o jej znaczeniu dla koncepcji bezpieczeństwa demokratycznego. Autor dokonuje wykładni postanowień preambuły Statutu Rady Europy, wskazując między innymi na nierozdzielność demokracji politycznej i demokracji społecznej, warunkując istnienie stanu pokoju postępem ekonomicznym i społecznym. Do rozważań zostaje wprowadzone bardzo interesujące pojęcie inżynierii demokratycznej (democratic engineering), pod którym rozumie się wykorzystanie doświadczenia i ekspertyz, dla osiągnięcia zamierzonych celów w postaci ustanowienia pluralistycznej demokracji opartej na prawach człowieka i rządach prawa. Zaznaczyłbym, że proces petryfikacji demokracji nie przebiega w państwach członkowskich Rady Europy w sposób liniowy i bezproblemowy. Owe ekspertyzy i podejmowane w oparciu o nie działania nie zawsze są powszechnie akceptowane w państwach członkowskich Rady 
Europy. Praktyka dowodzi, że w państwach, w których po przejściu ustrojowej transformacji, standardy europejskie - jak mogłoby się wydawać - okrzepły, pojawiają się poważne wątpliwości co do respektowania konstytucyjnych podstaw demokracji i praworządności. Jednym z celów Rady Europy jest dążenie do osiągnięcia „spójności demokratycznej” w państwach członkowskich. Praktyka - także świeża praktyka dowodzi - że państwa członkowskie Rady Europy nie tworzą pod tym względem homogenicznej jedności. Oznacza to konieczność powrotów do korzeni budowy Rady Europy i jej aksjologii.

W tym kontekście należy podkreślić nieprzemijające znaczenie między innymi takich wartości i mechanizmów, jak: rządy prawa, budowanie zaufania obywateli do państwa, lojalność państwa wobec obywateli (wszystkich), niezawisłość i niezależność władzy sądowniczej, w tym sądownictwa konstytucyjnego, gwarancje pluralizmu politycznego, ochrona praw opozycji, cywilna kontrola nad armią i inne.

Zgodnie z logiką, po prezentacji zagadnienia bezpieczeństwa demokratycznego w działalności Rady Europy, w ostatnim czwartym rozdziale książki omówione zostały problemy, jakie napotyka wykonanie koncepcji bezpieczeństwa demokratycznego w państwach członkowskich Rady Europy. Istotą tej części publikacji jest analiza i ocena praktycznego oddziaływania instrumentów Rady Europy na kształtowanie obszaru demokratycznego bezpieczeństwa. Innym słowy, Autor dokonuje oceny efektywności poszczególnych narzędzi Rady Europy w tym zakresie, czyniąc to w oparciu o solidną podstawę w postaci analizy materiału normatywnego oraz praktycznych case'ów.

Celem jaki postawił sobie Autor, było zbadanie wpływu Rady Europy na wykonanie koncepcji bezpieczeństwa demokratycznego w państwach członkowskich tej organizacji. Autor dokonał czytelnej prezentacji aksjologii Rady Europy w tym zakresie, zidentyfikował składowe bezpieczeństwa demokratycznego, wskazał na kluczowe narzędzia organizacji wykorzystywane w budowie i obronie bezpieczeństwa demokratycznego, jak również na problemy, jakie ten proces napotyka. Rada Europy jest strażnikiem bezpieczeństwa demokratycznego i zagadnienie to silnie eksponuje w swojej działalności. Zagrożenia dla bezpieczeństwa demokratycznego w mniejszym stopniu biorą źródło z nierównowagi militarnej, a w większym stopniu wynikają z zakłóceń procesu konsolidacji politycznej czy z wewnętrznych konfliktów o podłożu etnicznym, religijnym bądź innym. 
Nie należy stawiać znaku równości między bezpieczeństwem demokratycznym a demokratyczną legitymacją. Wszak także demokratycznie wybrana władza jest narażona na pokusę demontażu bezpieczeństwa demokratycznego. Stąd potrzeba ograniczania tej władzy standardami demokracji, praworządności i praw człowieka wyrażonymi w postanowieniach konstytucji i umów międzynarodowych, na straży których stoją krajowe sądy konstytucyjne, sądy europejskie, w tym Europejski Trybunał Praw Człowieka, wydające prawnie wiążące orzeczenia, jak również inne instytucje, wyposażone w bardziej „aksamitne” narzędzia oddziaływania. Wszystkie te narzędzia, zarówno te o oddziaływaniu „twardym”, jak np. Europejski Trybunał Praw Człowieka, czy o oddziaływaniu „miękkim”, jak Komisarz Praw Człowieka, czy o oddziaływaniu jedynie doradczym, jak Komisja Wenecka - wszystkie one w założeniu dostarczają demokratycznych sposobów rozładowywania konfliktów. Bezpieczeństwu demokratycznemu służy prewencyjne, tudzież następcze eliminowanie zagrożeń tej wartości.

Autor oparł swą pracę o rozbudowaną i należycie wyprofilowaną bazę źródłową. Składa się na nią około 730 zróżnicowanych charakterem źródeł. Już sama liczba pozyskanych źródeł dowodzi znacznego wysiłku na rzecz budowy warsztatu badawczego. W pracy wykorzystano źródła w językach: polskim oraz w wiodącym w Radzie Europy języku angielskim.

W moim odczuciu badacza zagadnień dotyczących Rady Europy, Europejskiej Konwencji Praw Człowieka i Europejskiego Trybunału Praw Człowieka, jak również wpływu tych: organizacji, traktatu oraz orzecznictwa na porządki prawne państw stron - Konwencji, recenzowana książka stanowi opracowanie o wysokim merytorycznym poziomie. Cechuje je oryginalność tematu, treści oraz ujęć zagadnień składowych. W książce tej elementy politologiczne zostały umiejętnie spojone z elementami prawnymi. Jej lektura skutkuje świeżością odbioru, co dowodzi lekkiego pióra Autora. Rzecz jest także bardzo dobrze udokumentowana. Publikacja zawiera w sobie ową „wartość dodaną", co stanowi istotę badań naukowych. Jest to pierwsze w naszej literaturze zbiorcze, obszerne i spójne opracowanie na ten temat, wcześniej podejmowany jedynie w rozproszonym piśmiennictwie. 